\title{
Baicalin attenuates DDP (cisplatin) resistance in lung cancer by downregulating MARK2 and p-Akt
}

\author{
ZHIWEI XU ${ }^{1}$, JU MEI ${ }^{1}$ and YAN TAN ${ }^{2}$ \\ ${ }^{1}$ Department of Cardiothoracic Surgery, Xinhua Hospital, Shanghai Jiaotong University School of Medicine, \\ Shanghai; ${ }^{2}$ Department of Intensive Care Unit, Shanghai Pudong Hospital, Fudan University \\ Pudong Medical Center, Pudong, Shanghai 201399, P.R. China
}

Received September 12, 2016; Accepted November 4, 2016

DOI: $10.3892 /$ ijo.2016.3768

\begin{abstract}
DDP (cisplatin) resistance in lung cancer has been widely reported. Baicalin is a flavone glycoside found in genus Scutellaria. However, the effects of baicalin on DDP resistance in lung cancer are unclear. The aim of present study was to investigate effects of combination of baicalin and DDP on proliferation and invasion of human lung cancer cells, and explore possible mechanisms. MTT assay was utilized to evaluate effects of baicalin and DDP on the proliferation of A549 and A549/DPP (DPP-resistant) human lung cancer cells. The probability sum method was used to determine effects of the drug combination. Transwell invasion assay was utilized to detect tumor cell invasion. The mRNA expression of MARK2 in A549 and A549/DPP cells was detected by qPCR. Protein expression of MARK2, p-Akt and Akt was detected by western blot analysis. Baicalin and DPP when used alone inhibited the proliferation of A549 and A549/DDP cells in a dose-dependent manner at 24 and $48 \mathrm{~h}$. For A549 cells, baicalin $(8 \mu \mathrm{g} / \mathrm{ml})$ antagonized DDP $(1,2,4$ and $8 \mu \mathrm{g} / \mathrm{ml})$ at $24 \mathrm{~h}$. For A549/DDP cells, baicalin and DDP were additive when the concentration of DDP was $4 \mu \mathrm{g} / \mathrm{ml}$ at $24 \mathrm{~h}$. Effects of baicalin and DDP on proliferation inhibition were additive and synergistic when concentrations of DDP were 8 and $4 \mu \mathrm{g} / \mathrm{ml}$, respectively, at $48 \mathrm{~h}$ for both A549 and A549/DDP cells. When baicalin $(8 \mu \mathrm{g} / \mathrm{ml})$ and DDP $(4 \mu \mathrm{g} / \mathrm{ml})$ were combined, the inhibitory rate of tumor cell invasion increased markedly compared to DPP or baicalin alone groups in both A549 and A549/DDP cells. A549/DDP cells had significantly higher MARK2 mRNA levels and protein expression of MARK2 and p-Akt. Baicalin decreased MARK2 mRNA and protein expression of MARK2 and p-Akt in A549/DDP cells dose-dependently. In conclusion, baicalin and DDP were synergistic at inhibiting proliferation and invasion of human lung cancer cells at appropriate dosages and incubation time
\end{abstract}

Correspondence to: Dr Yan Tan, Department of Intensive Care Unit, Shanghai Pudong Hospital, Fudan University Pudong Medical Center, 2800 Gong Wei Road, Pudong, Shanghai 201399, P.R. China E-mail: 18610081078@163.com

Key words: lung cancer, chemoresistance, baicalin, DDP, cisplatin in the presence or absence of DDP resistance. The attenuation of DDP resistance was associated with downregulation of MARK2 and p-Akt.

\section{Introduction}

Lung cancer is the most common cancer in men worldwide, and is the fourth most frequent cancer in women (1). The standard therapy of intermediate and advanced lung cancer is based on the combination of Cis-diamminedichloroplatinum (DDP, cisplatin) and other chemotherapy agents (2,3). DDP is a DNA cross-linking agent, which is used to treat cancers such as lung, ovarian and cervical cancers (4-6). Cisplatin, carboplatin and oxaliplatin induce cross-links between guanine bases. Cisplatin and carboplatin form an identical cross-link, whereas the cross-link of oxaliplatin is structurally different because of the bulky 1,2-diaminocyclohexane group. However, DDP resistance in lung cancer has been widely reported (7-9).

Baicalin is a flavone glycoside found in several species in the genus Scutellaria, such as Scutellaria baicalensis and Scutellaria lateriflora. Baicalin and its aglycone baicalein are positive allosteric modulator of benzodiazepine and nonbenzodiazepine sites of GABAA receptor $(10,11)$. Baicalin was shown to display anxiolytic effects without sedative effects in mice $(12,13)$. Moreover, baicalin was revealed to inhibit prolyl endopeptidase (14), and induce apoptosis in pancreatic cancer cells (15). Baicalin also inhibited proliferation of other malignant tumors, such as hepatocellular carcinoma and glioma $(16,17)$. However, the effects of baicalin on DDP resistance in lung cancer are unclear.

Microtubule affinity-regulating kinase 2 (MARK2) is serine/threonine-protein kinase that is involved in the control of cancer, microtubule stability, and cell polarity. MARK2 has been shown to interact with Akt (18). The phosphoinositide 3 kinase (PI3K)/Akt mammalian target of rapamycin (mTOR) regulates cell cycling, and is associated with cellular proliferation and the development of cancer. Once activated, PI3K phosphorylates and activates Akt, which has numerous downstream effects, including activating mTOR (19). Overactivation of the mTOR pathway leads to increased cell proliferation and reduced levels of cellular apoptosis involved in the pathogenesis of cancer. p-Akt is the activated form of Akt that has biological function. Therefore, we examined the 
expressions of MARK2 and p-Akt as a means of exploring the effects of combination of baicalin and DDP on proliferation and invasion of human lung cancer cells.

\section{Materials and methods}

Cells and reagents. Cells. A549 cells (human lung cancer cells) and A549/DDP cells (DDP-resistant human lung cancer cells) were purchased from MeiXuan Biological Science and Technology, Inc. (Shanghai, China), and cultured at $37^{\circ} \mathrm{C}$ in F12K medium supplemented with $100 \mathrm{ml} / \mathrm{l}$ fetal bovine serum (FBS), $100 \mathrm{kU} / \mathrm{l}$ penicillin, and $100 \mathrm{mg} / \mathrm{l}$ chloramphenicol in a cell incubator with $5 \% \mathrm{CO}_{2}$. Drugs: the baicalin powder (Ronghe Inc., Shanghai, China) and cisplatin (DDP; Macklin Inc., Shanghai, China) were dissolved in dimethyl sulfoxide (DMSO). Both solutions were stored at $-80^{\circ} \mathrm{C}$.

Main reagents. F12K culture medium; RPMI-1640 culture medium; fetal bovine serum (FBS); trypsin and antibodies (all from Gibco Inc., Grand Island, NY, USA); MTT cell proliferation and toxicity assay kits (Aladdine Inc., Shanghai, China); primary antibodies against GAPDH (Abcam Inc., Cambridge, MA, USA); primary antibodies against Akt and p-Akt (Cell Signaling Technology Inc., Danvers, MA, USA); primary antibodies against MARK2 (Proteintech Inc., Rosemont, IL, USA); goat anti-rabbit antibody (Invitrogen Inc., Grand Island, NY, USA); Martrigel (Becton-Dickinson Inc., Franklin Lakes, NJ, USA); Transwell (Corning Inc., Corning, NY, USA); TRIzol (Invitrogen Inc., Grand Island, NY, USA); Takara Reverse Transcriptase M-MLV; qPCR kit (Tiangen Biotech, Inc., Beijing, China); and specific primers for MARK2 and $\beta$-actin (Sangon Biotech Inc., Shanghai, China).

Main pieces of equipment: light microscope (Olympus Inc., Tokyo, Japan); microplate reader (Kehua Inc., Shanghai, China); table-type refrigerated centrifuge (USTC Zonkia Inc., Hefei, China); cell incubator (Thermo Scientific Inc., Waltham, MA, USA); vertical and horizontal electrophoresis system (Liuyi, Inc., Beijing, China); electric thermostatic drying oven (Huyue, Inc., Shangyu, China); PCR machine (Bio-Rad Inc., Irvine, CA, USA); and Step One Plus quantitative PCR machine (Applied Biosystems, Inc., Waltham, MA, USA).

MTT assay. A549/DDP cells were cultured for $24 \mathrm{~h}$ before baicalin was added. The final concentrations of baicalin were $1,2,4$ and $8 \mu \mathrm{g} / \mathrm{ml}$ ( $\mathrm{n}=3$ wells/each concentration). The final concentrations of DDP were 1, 2, 4 and $8 \mu \mathrm{g} / \mathrm{ml}$. No drug was added in control group. Meanwhile, other aliquots of cells were treated with baicalin $(8 \mu \mathrm{g} / \mathrm{ml})$, DDP $(1,2,4$ and $8 \mu \mathrm{g} / \mathrm{ml})$, and baicalin $(8 \mu \mathrm{g} / \mathrm{ml})$ combined with DDP $(1,2,4$ and $8 \mu \mathrm{g} / \mathrm{ml})$ respectively ( $\mathrm{n}=3$ wells/each concentration). Following addition of drugs, cells were cultured in a $37^{\circ} \mathrm{C}$ incubator with $5 \% \mathrm{CO}_{2}$ for periods of 24 and $48 \mathrm{~h}$, respectively. Following culture, $20 \mu \mathrm{l}$ of MTT solution $(5 \mathrm{mg} / \mathrm{ml})$ was added to each well, and the cells were cultured at $37^{\circ} \mathrm{C}$ for an additional $4 \mathrm{~h}$. Following culture, the cell supernatants were removed and discarded, and $150 \mu \mathrm{l}$ of DMSO was added to each well. The plates were then shaken for $15 \mathrm{~min}$ to dissolve crystals, and the absorbance of each sample was detected at $570 \mathrm{~nm}$ (A570) using an ELISA microplate reader. The degree of cell proliferation inhibition in each sample was calculated using the following formula: cell proliferation inhibition $(\%)=(1$-absorbance of the experimental group/absorbance of the control group) x $100 \%$. The probability sum method was utilized to look for evidence of synergism achieved by combining baicalin with cisplatin (20). The formula used for this purpose was $\mathrm{q}=\mathrm{EAB} /(\mathrm{EA}+\mathrm{EB}-\mathrm{EAxEB})$, where $E A B$ is the effect achieved (e.g., inhibition rate) when drug $A$ and $B$ are combined, and EA and EB are the effects of drug A and B, respectively, when applied separately. A q-value between 0.85 and 1.15 indicates that the effects of drug $\mathrm{A}$ and $\mathrm{B}$ are additive. A q-value $>1.15$ indicates that the effects of drug $\mathrm{A}$ and $\mathrm{B}$ are synergistic, while a q-value $<0.85$ indicates that drug $\mathrm{A}$ and $\mathrm{B}$ have antagonistic effects.

Transwell invasion assay. A549 and A549/DDP cells were treated with baicalin $(8 \mu \mathrm{g} / \mathrm{ml})$, DDP $(4 \mu \mathrm{g} / \mathrm{ml})$, and baicalin $(8 \mu \mathrm{g} / \mathrm{ml})$ combined with DDP $(4 \mu \mathrm{g} / \mathrm{ml})$ for $48 \mathrm{~h}$, respectively ( $\mathrm{n}=3 /$ group). No drugs were added in control groups. Cells were digested by trypsin-ethylene diamine tetraacetic acid (EDTA) solution $(0.25 \%$ EDTA) and centrifuged. The cells were then diluted to make concentration of $5 \times 10^{5} / \mathrm{ml}$. The membrane of the upper compartment was coated with $50 \mu \mathrm{l}$ of Matrigel $(1 \mathrm{~g} / \mathrm{l})$, and incubated at $37^{\circ} \mathrm{C}$ for $1 \mathrm{~h}$ in order to reconstruct its structure into basal membrane. Two hundred microliters of A549 and A549/DPP cell suspension were incubated in upper compartment of Transwell respectively, and $600 \mu 1$ of $20 \%$ FBS were added into lower compartment. Cells were incubated at a humid incubator with $5 \% \mathrm{CO}_{2}$ for $48 \mathrm{~h}$. Following culture, $4 \%$ paraformaldehyde was utilized to fix the microporous membrane. Cells were stained with $0.05 \%$ crystal violet for $10 \mathrm{~min}$, and washed with phosphate-buffered saline (PBS) twice. Cells were then observed under microscope (x400), and the number of cells that penetrated the membrane were counted. The inhibition of tumor cell invasion was calculated utilizing the following formula: inhibition of cell invasion $(\%)=(1-$ the average number of cells that penetrated the membrane in the experimental group/the average number of cells that penetrated the membrane in the control group) $\mathrm{x} 100 \%$.

Quantitative polymerase chain reaction ( $q P C R)$. A549/DDP cells were treated with different concentrations of baicalin $(0$, $1,2,4,8$ and $10 \mu \mathrm{g} / \mathrm{ml}$ ) for $48 \mathrm{~h}$. Total RNA of A549/DDP cells was extracted and purified by TRIzol according to manufacturer's instructions. A universal cDNA synthesis kit (Tiangen Biotech, Inc.) was utilized for reverse transcription. Each reaction contained $1 \mu \mathrm{l}$ of random hexamer primers $(0.2 \mu \mathrm{g} / \mu \mathrm{l})$ and $40 \mathrm{U}$ M-MuLV reverse transcriptase $(20 \mathrm{U} / \mu \mathrm{l})$. The specific primer for detection of MARK2 gene was forward, ATGCTGC CCCAGAACTCTTC and reverse, GTGCCTCTCTTGCTGG GATT. The specific primer for detection of $\beta$-actin gene was forward, AGAAAATCTGGCACCACACC and reverse, AGA GGGTACAGGGATAGCA. miRcute miRNA qPCR detection kit was used for qPCR. PCR conditions were as follows: pre-denaturing at $95^{\circ} \mathrm{C}$ for $15 \mathrm{~min}$; denaturing at $95^{\circ} \mathrm{C}$ for $10 \mathrm{sec}$; and annealing and polymerization at $60-66^{\circ} \mathrm{C}$ for 20-32 sec. There were 40 PCR cycles. PCR was performed in an ABI Step One Plus qPCR system. The expression of MARK2 was determined as the ratio of relative optical density of target gene to $\beta$-actin.

Western blot studies. Expression levels of AKT, p-AKT and MARK2 proteins were detected by western blot analysis. 
Table I. Effects of baicalin and DDP on the proliferation of A549 cells.

\begin{tabular}{|c|c|c|c|c|c|c|c|c|c|}
\hline A549 cells & $\begin{array}{l}\text { Baicalin } \\
\quad\left(8^{\mathrm{a}}\right)\end{array}$ & $\begin{array}{l}\text { DDP } \\
(1)\end{array}$ & $\begin{array}{l}\text { DDP } \\
(2)\end{array}$ & $\begin{array}{l}\text { DDP } \\
(4)\end{array}$ & $\begin{array}{l}\text { DDP } \\
(8)\end{array}$ & $\begin{array}{l}\text { Baicalin (8) } \\
+ \text { DDP (1) }\end{array}$ & $\begin{array}{l}\text { Baicalin (8) } \\
+\operatorname{DDP}(2)\end{array}$ & $\begin{array}{l}\text { Baicalin (8) } \\
+ \text { DDP (4) }\end{array}$ & $\begin{array}{l}\text { Baicalin (8) } \\
+ \text { DDP (8) }\end{array}$ \\
\hline \multicolumn{10}{|l|}{ A549 cells/24 h } \\
\hline EA & 0.20 & & & & & & & & \\
\hline $\mathrm{EB}$ & & 0.13 & 0.20 & 0.22 & 0.31 & & & & \\
\hline EAB & & & & & & 0.10 & 0.18 & 0.28 & 0.36 \\
\hline $\begin{array}{l}q=(E A B / \\
(E A+E B-E A x E B)\end{array}$ & & & & & & 0.31 & 0.50 & 0.74 & 0.80 \\
\hline \multicolumn{10}{|l|}{ A549 cells/48 h } \\
\hline EA & 0.21 & & & & & & & & \\
\hline EB & & 0.17 & 0.21 & 0.26 & 0.41 & & & & \\
\hline EAB & & & & & & 0.26 & 0.29 & 0.49 & 0.50 \\
\hline $\begin{array}{l}\mathrm{q}=(\mathrm{EAB} / \\
(\mathrm{EA}+\mathrm{EB}-\mathrm{EAxEB})\end{array}$ & & & & & & 0.76 & 0.76 & $1.20^{\mathrm{b}}$ & $0.94^{\mathrm{c}}$ \\
\hline $\begin{array}{l}\text { MTT assay was utilize } \\
\text { used to determine effec } \\
\text { EA and EB are the effec } \\
\text { Drug A and B are syne } \\
2,4 \text { and } 8 \mu \mathrm{g} / \mathrm{ml} \text { at } 24 \\
\text { was } 8 \mu \mathrm{g} / \mathrm{ml} \text {, and syner } \\
\text { the table is } \mu \mathrm{g} / \mathrm{ml} \text {; }{ }^{\text {b }} \text { syn }\end{array}$ & $\begin{array}{l}\text { to detect ce } \\
\text { s of the drug } \\
\text { s of separate } \\
\text { istic if } \mathrm{q}>1 \text {. } \\
\text { after A549 } \\
\text { istic when tl } \\
\text { rgist effects; }\end{array}$ & $\begin{array}{l}\text { prolifer } \\
\text { combina } \\
\text { reatmen } \\
5 \text {, and ar } \\
\text { ells were } \\
\text { concen } \\
\text { additive }\end{array}$ & $\begin{array}{l}\text { tion. Da } \\
\text { lon. For } \\
\text { with dr } \\
\text { agonisti } \\
\text { treated. } \\
\text { ation of } \\
\text { ffects. }\end{array}$ & $\begin{array}{l}\text { for inhi } \\
\text { ula: } \mathrm{q}=\mathrm{E} \\
\mathrm{A} \text { and } \mathrm{B} \\
\text { if } \mathrm{q}<0.8 \\
\text { addition } \\
\mathrm{DP} \text { was }\end{array}$ & $\begin{array}{l}\text { ition of } \\
\mathrm{B} /(\mathrm{EA}- \\
\text { alone. } \mathrm{T} \\
\text { Baicali } \\
\text { effects } \\
\mu \mathrm{g} / \mathrm{ml}\end{array}$ & $\begin{array}{l}\text { ell proliferation } \\
\text { B-EAxEB). EA } \\
\text { effects of drug } \\
(8 \mu \mathrm{g} / \mathrm{ml}) \text { antag } \\
\text { baicalin and D } \\
48 \mathrm{~h} \text {. DDP, cis- }\end{array}$ & $\begin{array}{l}\text { mean values). } \\
3 \text { is the effect } \mathrm{W} \\
\text { and B are addit } \\
\text { nized DDP whe } \\
\mathrm{P} \text { were additive } \\
\text { iamminedichlor }\end{array}$ & $\begin{array}{l}\text { e probability } \mathrm{su} \\
\text { en drug A and } \mathrm{B} \\
\text { ve if } \mathrm{q} \text { is betwee } \\
\text { concentrations } \\
\text { when the concer } \\
\text { platinum, cispla }\end{array}$ & $\begin{array}{l}\text { m method was } \\
\text { are combined. } \\
0.85 \text { and } 1.15 \text {. } \\
\text { f DDP were } 1 \text {, } \\
\text { ration of DDP } \\
\text { in. }{ }^{a} \text { The unit in }\end{array}$ \\
\hline
\end{tabular}

A 549/DPP cells were treated with different concentrations of baicalin $(1,2,4$ and $8 \mu \mathrm{g} / \mathrm{ml})$ for $48 \mathrm{~h}$. No drug was added in control group. Cellular proteins were extracted and separated by electrophoresis $(120 \mathrm{~V})$ on a $10 \%$ SDS-polyacrylamide gel. The separated proteins were then electrophoretically $(100 \mathrm{~V}$ for $120 \mathrm{~min}$ ) transferred to polyvinylidene fluoride (PVDF) membranes. After being blocked with $5 \%$ non-fat milk powder for $1 \mathrm{~h}$, the membranes were incubated with anti-Akt (1:1,000), anti-p-Akt $(1: 1,000)$, anti-MARK2 $(1: 2,000)$, and anti-GAPDH antibodies $(1: 5,000)$ respectively at $4^{\circ} \mathrm{C}$ overnight. Following incubation, membranes was washed three times (10 min each) with a solution of Tris-buffered saline and Tween-20 (TBST). The membranes were then incubated for $1 \mathrm{~h}$ at room temperature with goat anti-rabbit secondary antibody labeled with horseradish peroxidase (HRP) $(1: 3,000)$; after which, they were washed and incubated for a short time period in electro-chemi-luminescence (ECL) solution. The film was exposed in a dark room.

Statistical analysis. The statistical data were analyzed and the figures were created using GraphPad Prism 5.0 software (GraphPad Software Inc., La Jolla, CA, USA). All statistical results are expressed as the mean \pm SEM. Differences among 3 or more groups were compared by analysis of variance (ANOVA), followed by the Bonferroni post-hoc test for multiple comparisons. $\mathrm{p}$-values $\leq 0.05$ were considered statistically significant.

\section{Results}

Baicalin and DDP inhibit the proliferation of human lung cancer cells when used alone. MTT assay was utilized to evaluate effects of baicalin and DDP on the proliferation of A549 and A549/DPP human lung cancer cells. Following addition of drugs, cells were cultured for periods of 24 and $48 \mathrm{~h}$, respectively. The degree of cell proliferation inhibition was calculated as: inhibitory rate of cell proliferation $(\%)=(1-a b s o r b a n c e$ of the experimental group/absorbance of the control group) $\times 100 \%$. Our results showed that baicalin and DPP when used alone inhibited the proliferation of A549 cells in a dose-dependent manner at 24 and $48 \mathrm{~h}$, respectively (Fig. 1). Similarly, baicalin and DPP inhibited the proliferation of A549/DDP cells in a dose-dependent manner at 24 and $48 \mathrm{~h}$. The ability of baicalin to inhibit tumor cell proliferation was similar between A549 and A549/DDP cells, whereas the ability of DDP to inhibit cell proliferation was lower in A549/DDP cells (Fig. 1).

Effects of combination of baicalin and DDP on the proliferation of human lung cancer cells. MTT assay was utilized to evaluate effects of combination of baicalin and DDP on the proliferation of A549 and A549/DPP human lung cancer cells. Following addition of drugs, cells were cultured for periods of 24 and $48 \mathrm{~h}$, respectively. The probability sum method was used to determine effects of the drug combination. Formula: $\mathrm{q}=\mathrm{EAB} /(\mathrm{EA}+\mathrm{EB}-\mathrm{EAxEB})$. The effects of drug $\mathrm{A}$ and $\mathrm{B}$ are additive if $q$ is between 0.85 and 1.15. Drug $A$ and $B$ are synergistic if $\mathrm{q}>1.15$, and antagonistic if $\mathrm{q}<0.85$. Baicalin $(8 \mu \mathrm{g} / \mathrm{ml})$ antagonized DDP when concentrations of DDP were 1, 2, 4 and $8 \mu \mathrm{g} / \mathrm{ml}$ at $24 \mathrm{~h}$ after A549 cells were treated $(\mathrm{q}<0.85)$. The effects of baicalin and DDP were additive when the concentration of DDP was $8 \mu \mathrm{g} / \mathrm{ml}(0.85<\mathrm{q}<1.15)$, and synergistic when the concentration of DDP was $4 \mu \mathrm{g} / \mathrm{ml}$ at $48 \mathrm{~h}$ after A549 cells were treated ( $\mathrm{q}>1.15)$ (Table I). In addition, at $24 \mathrm{~h}$ after 
Table II. Effects of baicalin and DDP on the proliferation of A549/DDP cells.

\begin{tabular}{|c|c|c|c|c|c|c|c|c|c|}
\hline A549 cells & $\begin{array}{l}\text { Baicalin } \\
\quad\left(8^{\mathrm{a}}\right)\end{array}$ & $\begin{array}{l}\text { DDP } \\
(1)\end{array}$ & $\begin{array}{l}\text { DDP } \\
(2)\end{array}$ & $\begin{array}{l}\text { DDP } \\
(4)\end{array}$ & $\begin{array}{l}\text { DDP } \\
(8)\end{array}$ & $\begin{array}{l}\text { Baicalin (8) } \\
\text { + DDP (1) }\end{array}$ & $\begin{array}{l}\text { Baicalin (8) } \\
+ \text { DDP (2) }\end{array}$ & $\begin{array}{l}\text { Baicalin (8) } \\
+ \text { DDP (4) }\end{array}$ & $\begin{array}{l}\text { Baicalin (8) } \\
+\operatorname{DDP}(8)\end{array}$ \\
\hline \multicolumn{10}{|l|}{ A549/DDP cells/24 h } \\
\hline EA & 0.11 & & & & & & & & \\
\hline EB & & 0.10 & 0.12 & 0.13 & 0.21 & & & & \\
\hline EAB & & & & & & 0.07 & 0.09 & 0.21 & 0.21 \\
\hline $\begin{array}{l}\mathrm{q}=(\mathrm{EAB} / \\
(\mathrm{EA}+\mathrm{EB}-\mathrm{EAxEB})\end{array}$ & & & & & & 0.36 & 0.40 & $0.89^{\mathrm{b}}$ & 0.73 \\
\hline \multicolumn{10}{|l|}{ A549/DDP cells/48 h } \\
\hline EA & 0.19 & & & & & & & & \\
\hline $\mathrm{EB}$ & & 0.11 & 0.12 & 0.19 & 0.29 & & & & \\
\hline EAB & & & & & & 0.13 & 0.24 & 0.40 & 0.41 \\
\hline $\begin{array}{l}\mathrm{q}=(\mathrm{EAB} / \\
(\mathrm{EA}+\mathrm{EB}-\mathrm{EAxEB})\end{array}$ & & & & & & 0.48 & 0.84 & $1.17^{\mathrm{c}}$ & $0.95^{\mathrm{b}}$ \\
\hline $\begin{array}{l}\text { The effects of drug A and } \\
(8 \mu \mathrm{g} / \mathrm{ml}) \text { antagonized D } \\
\text { concentration of DDP w } \\
\text { concentration of DDP w } \\
\text { cisplatin. }{ }^{a} \text { The unit in the }\end{array}$ & $\begin{array}{l}\text { e additive } \\
\mathrm{when} \text { conc } \\
\mu \mathrm{g} / \mathrm{ml} \text { at } 2 \\
\mu \mathrm{g} / \mathrm{ml} \text {, anc } \\
\text { le is } \mu \mathrm{g} / \mathrm{m}\end{array}$ & $\begin{array}{l}\mathrm{fq} \text { is bet } \\
\text { entration } \\
4 \mathrm{~h} \text { after }\end{array}$ & $\begin{array}{l}\text { veen } 0.8 \\
\text { of DD } \\
549 / \mathrm{D}\end{array}$ & $\begin{array}{l}\text { and } 1.1 \\
\text { were } 1, \\
\text { P cells }\end{array}$ & $\begin{array}{l}\text { Drug Aa } \\
\text { nd } 8 \mu \mathrm{g} \\
\text { treated }\end{array}$ & $\begin{array}{l}\mathrm{d} \mathrm{B} \text { are syner } \\
\mathrm{nl} \text {, whereas e } \\
\text { In addition, e } \\
\text { DDP was } 4 \mu\end{array}$ & $\begin{array}{l}\text { if } \mathrm{q}>1.15 \text {, and } \\
\mathrm{s} \text { of baicalin an } \\
\mathrm{s} \text { of baicalin an } \\
\text { at } 48 \mathrm{~h} \text {. DDP, }\end{array}$ & $\begin{array}{l}\text { antagonistic if } \\
\text { nd DDP were ac } \\
\text { nd DDP were ac } \\
\text { cis-diamminedi }\end{array}$ & $\begin{array}{l}\text { 0.85. Baicalin } \\
\text { ditive when the } \\
\text { ditive when the } \\
\text { hloroplatinum, }\end{array}$ \\
\hline
\end{tabular}
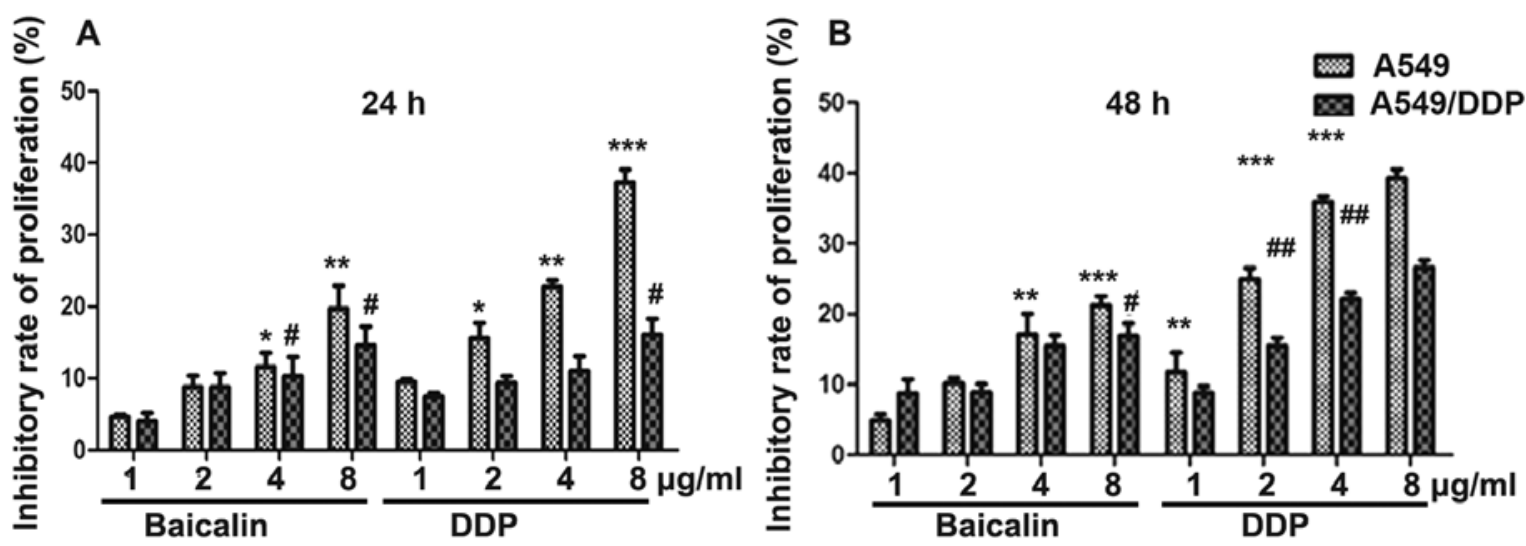

Figure 1. Baicalin and DDP inhibit the proliferation of human lung cancer cells when used alone. MTT assay was utilized to evaluate effects of baicalin and DDP on the proliferation of A549 and A549/DPP human lung cancer cells respectively. Following addition of drugs, cells were cultured for 24 and

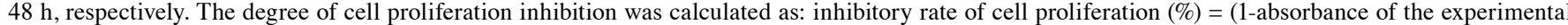
group/absorbance of the control group) x $100 \%$. (A) Inhibitory rate of tumor cell proliferation at $24 \mathrm{~h}$ after drug treatment. (B) Inhibitory rate of tumor cell proliferation at $48 \mathrm{~h}$ after drug treatment. Baicalin and DPP when used alone inhibited the proliferation of A549 and A549/DDP cells in a dose-dependent manner at 24 and $48 \mathrm{~h}$ (mean \pm SEM, $\mathrm{n}=3$ /group). ${ }^{*} \mathrm{p}<0.05,{ }^{* *} \mathrm{p}<0.01$ and ${ }^{* * *} \mathrm{p}<0.001$, respectively when compared with the baicalin $1 \mu \mathrm{g} / \mathrm{ml}$ group; ${ }^{*} \mathrm{p}<0.05$ and ${ }^{\# \#} \mathrm{p}<0.01$, respectively when compared with the DPP $1 \mu \mathrm{g} / \mathrm{ml}$ group. DDP, cis-diamminedichloroplatinum, cisplatin.

A549/DPP cells were treated, baicalin $(8 \mu \mathrm{g} / \mathrm{ml})$ antagonized DDP when concentrations of DDP were 1,2 and $8 \mu \mathrm{g} / \mathrm{ml}$ $(\mathrm{q}<0.85)$, whereas effects of baicalin and DDP were additive when the concentration of DDP was $4 \mu \mathrm{g} / \mathrm{ml}(0.85<\mathrm{q}<1.15)$. At $48 \mathrm{~h}$ after A549/DDP cells were treated, effects of baicalin and DDP were additive when the concentration of DDP was $8 \mu \mathrm{g} / \mathrm{ml}(0.85<\mathrm{q}<1.15)$, and synergistic when the concentration of DDP was $4 \mu \mathrm{g} / \mathrm{ml}$ ( $\mathrm{q}>1.15$ ) (Table II). In conclusion, synergistic effects of baicalin and DDP on proliferation of both A549 and A549/DDP cells were observed when concentrations of baicalin and DPP were 8 and $4 \mu \mathrm{g} / \mathrm{ml}$ respectively. Therefore, we used the dosages to examine tumor invasion.
Combination of baicalin and DDP enhances the invasion of human lung cancer cells. A549 and A549/DDP cells were treated with baicalin $(8 \mu \mathrm{g} / \mathrm{ml})$, DDP $(4 \mu \mathrm{g} / \mathrm{ml})$, and baicalin $(8 \mu \mathrm{g} / \mathrm{ml})$ combined with DDP $(4 \mu \mathrm{g} / \mathrm{ml})$ for $48 \mathrm{~h}$, respectively. Transwell invasion assay was used to detect the invasion of A549 and A549/DPP human lung cancer cells. When used alone, DDP and baicalin significantly inhibited the invasion of A549 ( $p<0.001)$ and A549/DDP cells (DDP, $p<0.001$; baicalin, $\mathrm{p}<0.01$ ) (Fig. 2) as compared to the control group. When DDP and baicalin were combined, the inhibitory rate increased markedly as compared to DPP or baicalin single treatment groups (p<0.001) (Fig. 2). 


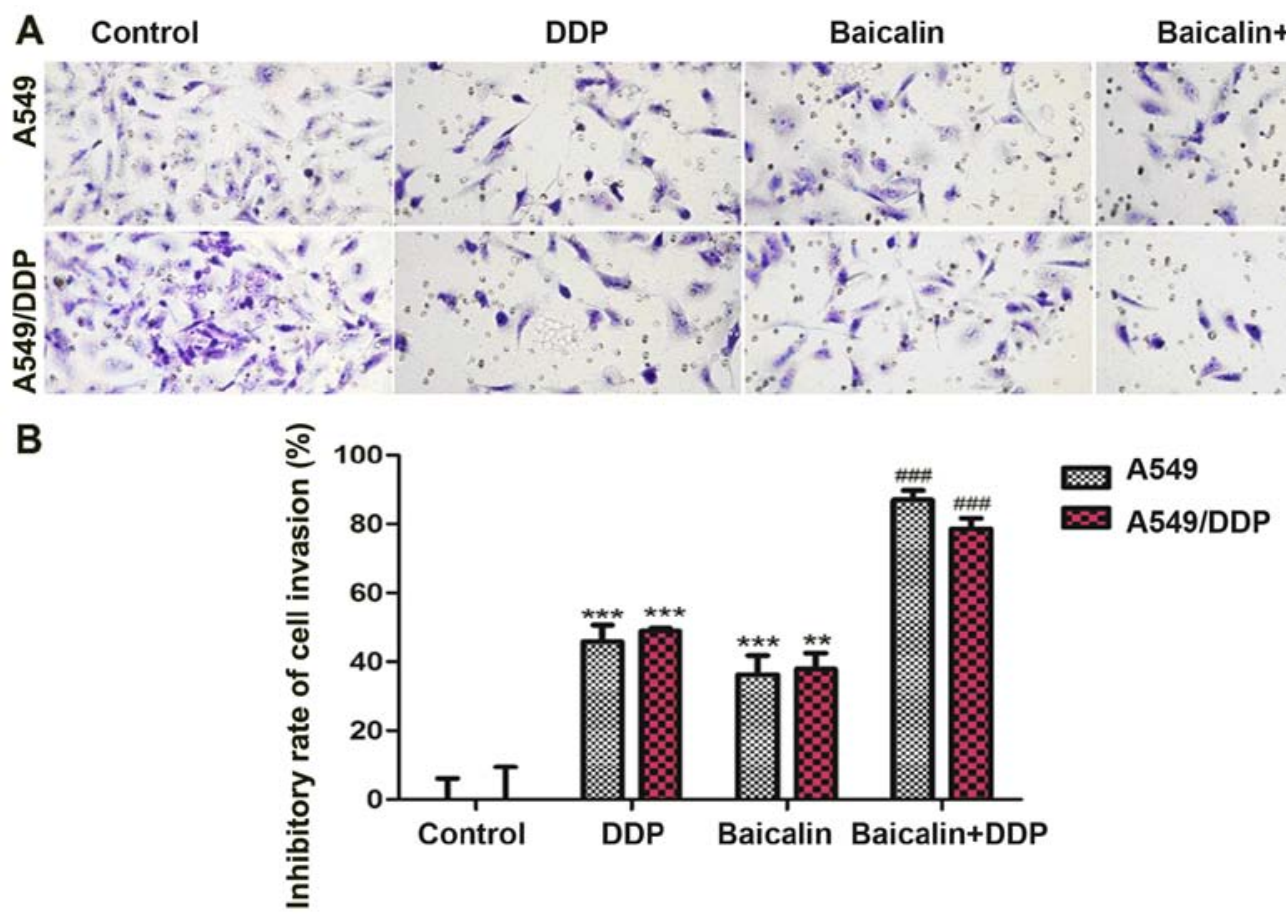

Figure 2. Effects of baicalin and DDP on the invasion of human lung cancer cells. A549 and A549/DDP cells were treated with baicalin ( $8 \mu \mathrm{g} / \mathrm{ml})$, DDP $(4 \mu \mathrm{g} / \mathrm{ml})$, and baicalin $(8 \mu \mathrm{g} / \mathrm{ml})$ combined with DDP $(4 \mu \mathrm{g} / \mathrm{ml})$ for $48 \mathrm{~h}$, respectively. Transwell invasion assay was used to detect the invasion of tumor cells. (A) Microscopic images of Transwell results (x400). (B) Statistical analysis of inhibitory rates of tumor cell invasion. When used alone, DDP and baicalin significantly inhibited the invasion of A549 and A549/DDP cells as compared to the control group. When DDP and baicalin were combined, the inhibitory rate increased markedly as compared to DPP or baicalin alone groups (mean \pm SEM, $n=3 /$ group). ${ }^{* * * * * *} \mathrm{p}<0.05$ when compared with the control group; ${ }^{\# \# \#} \mathrm{p}<0.001$ when compared with DDP or baicalin group. DDP, cis-diamminedichloroplatinum, cisplatin.
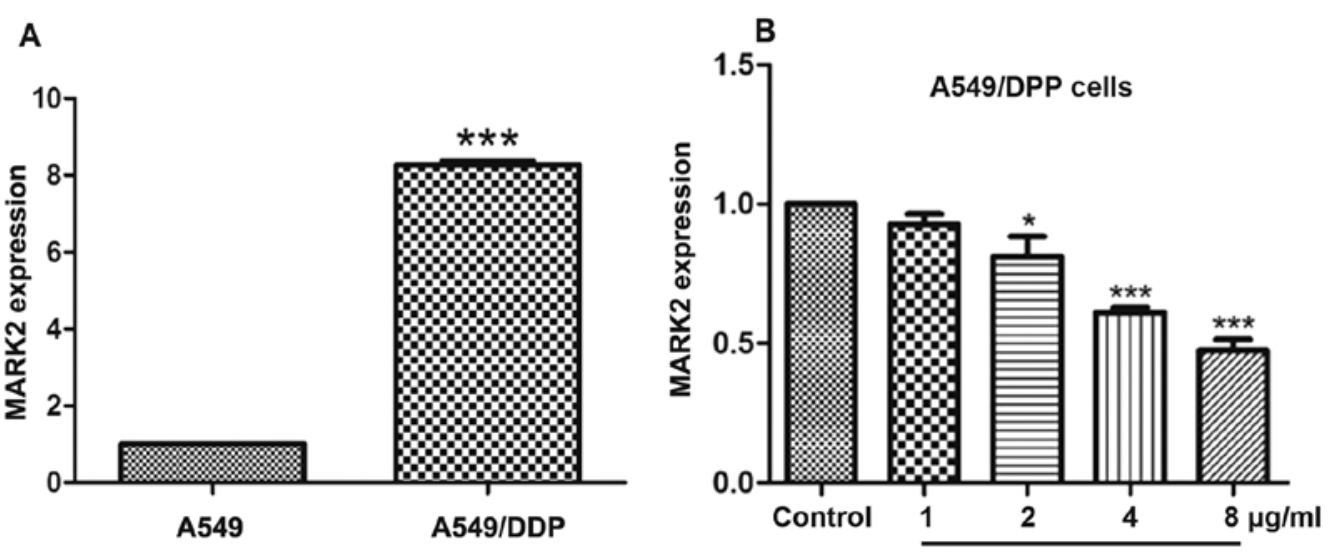

Figure 3. mRNA expression of MARK2 in human lung cancer cells. The mRNA expression of MARK2 in A549 and A549/DPP human lung cancer cells was detected by qPCR. (A) mRNA expression of MARK2 in A549 and A549/DDP cells. (B) Effects of different doses of baicalin on MARK2 mRNA expression in A549/DDP cells. A549/DDP cells had markedly higher MARK2 mRNA levels compared to A549 cells. Therefore, we chose A549/DDP cells to examine effects of different concentrations of baicalin on MARK2 mRNA expression. Baicalin decreased MARK2 mRNA levels in A549/DDP cells dose-dependently as compared to the control group (mean \pm SEM, $n=3$ /group). (A) ${ }^{* * *} \mathrm{p}<0.001$ as compared to A549 cells; (B) ${ }^{*} \mathrm{p}<0.05$ and ${ }^{* * *} \mathrm{p}<0.001$ when compared with the control group. Ctrl, control; DDP, cis-diamminedichloroplatinum, cisplatin.

mRNA expression of MARK2 in human lung cancer cells. The mRNA expression of MARK2 in A549 and A549/DPP human lung cancer cells was detected by qPCR. A549/DDP cells had markedly higher MARK2 mRNA levels compared to A549 cells $(\mathrm{p}<0.001)$ (Fig. 3A). Therefore, we chose A549/DDP cells to examine effects of different concentrations of baicalin on MARK2 mRNA expression. Baicalin decreased MARK2 mRNA levels in A549/DDP cells dosedependently, and higher doses of baicalin $(2,4$ and $8 \mu \mathrm{g} / \mathrm{ml})$ markedly inhibited MARK2 mRNA expression $(\mathrm{p}<0.05$, $\mathrm{p}<0.001$ and $\mathrm{p}<0.001$, respectively) (Fig. 3B) when compared to the control group.

Protein expression of Akt, $p$-Akt and MARK2 in human lung cancer cells. Protein expression of Akt, p-Akt and MARK2 was detected by western blot analysis. Relative protein expression of Akt, p-Akt and MARK2 to GAPDH was calculated. There were no differences in Akt expression between A549 and A549/DDP cells. The protein expression of p-Akt and MARK2 was markedly higher in A549/DDP cells as compared 


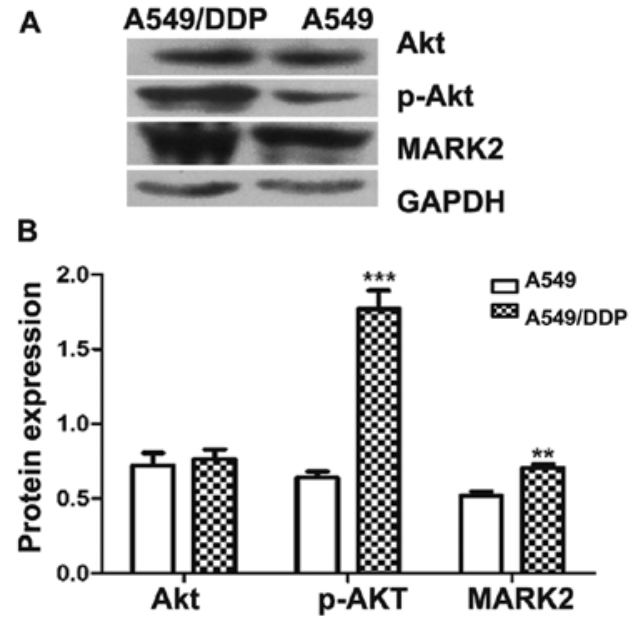

Figure 4. Protein expression of Akt, p-Akt and MARK2 in A549 and A549/DDP cells. Protein expression was detected by western blot analysis. Relative protein expression of Akt, p-Akt and MARK2 to GAPDH was calculated. (A) Western blot results show protein expression of Akt, p-Akt and MARK2 in A549 and A549/DDP cells. (B) Quantification of relative fold-change in blot density when compared with density of GADPH. The protein expression of p-Akt and MARK2 was markedly higher in A549/DDP cells as compared to A549 cells (mean $\pm \mathrm{SD}, \mathrm{n}=3$ /group). ${ }^{* *} \mathrm{p}<0.01$ and ${ }^{* * * *} \mathrm{p}<0.001$ when compared to A549 cells. DDP, cis-diamminedichloroplatinum, cisplatin.

to A549 cells (p-Akt: $\mathrm{p}<0.001$; MARK2: $\mathrm{p}<0.01$ ) (Fig. 4). Therefore, we chose A549/DDP cells to examine effects of different doses of baicalin on protein expression of MARK2, p-Akt, and Akt. Baicalin decreased protein expression of MARK2 and p-Akt in A549/DDP cells in a dose-dependent manner, whereas it did not alter protein expression of Akt. At higher doses $(2,4$ and $8 \mu \mathrm{g} / \mathrm{ml})$, baicalin significantly inhibited protein expression of MARK2 and p-Akt in A549/DDP cells as compared to the control group $(\mathrm{p}<0.01, \mathrm{p}<0.001$ and $\mathrm{p}<0.001$, respectively) (Fig. 5).

\section{Discussion}

We demonstrated that baicalin and DDP were synergistic at inhibiting proliferation and invasion of human lung cancer cells at appropriate dosages and incubation time in the presence or absence of DDP resistance. In addition, the attenuation of DDP resistance was associated with downregulation of MARK2 and p-Akt.

Lung cancer is the leading cause of cancer-related death worldwide (21). DDP was the first member of a class of platinum-containing anticancer drugs. These platinum complexes react in vivo and cause DNA cross-linking, which ultimately triggers cell apoptosis (22). Like other chemotherapeutic agents, resistance to DDP is inevitable and frequently occurs after several cycles of treatment. DDP resistance has been reported to be associated with mechanisms such as DNA damage/repair proteins, drug retention such as increased influx or decreased uptake, increased drug inactivation or prevention of drug to reach DNA target, growth signaling via different pathways or increase in anti-apoptotic proteins, and hypoxiainduced autophagy (23-28).

Studies have proposed measures to decrease DDP resistance. mTOR inhibitor (CCI-779) was revealed to be able to restore sensitivity to DDP in lung cancer (29). Inhibition of miR-196a reversed DDP resistance of A549/DDP cell lines, which may be linked to inhibition of drug efflux, downregulation of drug-resistant protein expression, cell apoptosis, and suppression of cell proliferation (30). Moreover, a fusion protein based on two tumstatin-derived sequences named recombinant VBMDMP (rVBMDMP) decreased cancer cell resistance to DDP in A549/DDP cell xenograft model of nude mice (31). Epigallocatechin-3-gallate (EGCG), the major polyphenol in green tea, was also shown to resensitize non-small cell lung cancer cells to DDP via demethylation of candidate genes.

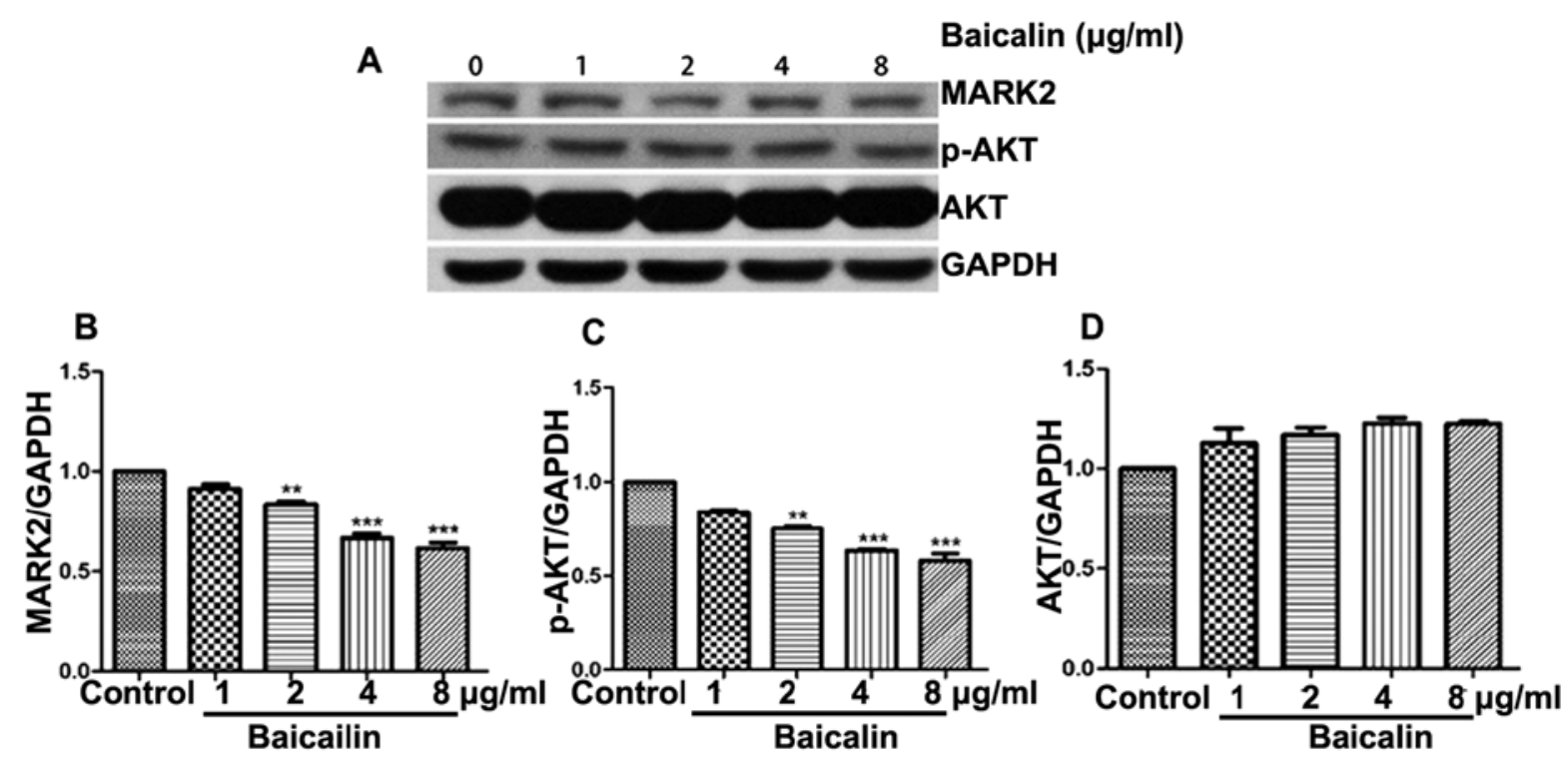

Figure 5. Effects of baicalin on protein expression of MARK2, p-Akt and Akt in A549/DDP cells. Protein expression was detected by western blot analysis Relative protein expression of Akt, p-Akt and MARK2 to GAPDH was calculated. (A) Western blot results show protein expression of Akt, p-Akt and MARK2 in A549/DDP cells after baicalin treatment. (B-D) Quantification of relative fold-change in blot density when compared with density of GADPH Baicalin decreased protein expression of MARK2 and p-Akt in A549/DDP cells in a dose-dependent manner, whereas it did not alter protein expression of Akt (mean $\pm \mathrm{SD}, \mathrm{n}=3$ /group). ${ }^{* *} \mathrm{p}<0.01$ and ${ }^{* * * *} \mathrm{p}<0.001$ when compared to the control group. DDP, cis-diamminedichloroplatinum, cisplatin; Ctrl, Control. 
Some traditional Chinese medicines were revealed to protect cancer patients against treatment-related complications and reduce toxicity of conventional therapy (32-34). Baicalin, a flavone glycoside, was reported to inhibit proliferation of malignant tumors including hepatocellular carcinoma and glioma $(16,17)$. However, effects of baicalin on DDP resistance in lung cancer were unclear. The main principle of lung cancer therapy is to induce cell death or inhibit cell survival (35). Therefore, we explored effects of combination of baicalin and DDP on proliferation and invasion of human lung cancer cells.

We demonstrated in the present study that effects of baicalin and DDP on proliferation inhibition of A549 and A549/DDP cells were synergistic when concentrations of baicalin and DDP were 8 and $4 \mu \mathrm{g} / \mathrm{ml}$ at $48 \mathrm{~h}$ after incubation. At these dosages, the inhibitory rate of tumor cell invasion increased significantly compared to DPP or baicalin alone groups in both A549 and A549/DDP cells. These findings indicate that baicalin increases the sensitivity and decreases resistance of DDP in lung cancer cells, no matter whether lung cancer cells already are resistant to DDP or not. These findings provide another novel approach to decrease DDP resistance in human lung cancer.

We then unveiled that baicalin dose-dependently decreased expression of MARK2 and p-Akt in A549/DDP cells. Interestingly, we showed that DDP-resistant A549 cells had significantly higher expression of MARK2 and p-Akt as compared to non-DDP-resistant A549 cells. Hence, the decreased expression of MARK2 and p-Akt after baicalin treatment may be associated with decreased DDP resistance in human lung cancer cells.

The role of MARK2 in lung cancer was recently identified. MARK2 was shown to activate cell cycle and DNA repair. High MARK2 expression levels correlated with resistance to DDP (36). In addition, Akt is an essential kinase enzyme component of the PI3K/Akt/mTOR pathway, and is a downstream effector of PI3K (37). The PI3K/Akt/mTOR pathway is an important intracellular signaling pathway related to cellular quiescence, proliferation and cancer. Over-activation of the $\mathrm{PI} 3 \mathrm{~K} / \mathrm{Akt} / \mathrm{mTOR}$ pathway reduces apoptosis and stimulates proliferation, and both of these processes are involved in the pathogenesis of cancer. Akt amplification was revealed to increase DDP resistance in human lung cancer cells through the mTOR/p70S6K1 pathway (38). IL-6 signaling contributed to cisplatin resistance in non-small cell lung cancer via upregulation of anti-apoptotic molecules including Akt (39). Meanwhile, DDP resistance due to loss of fragile histidine triad (FHIT) was reported to be conquered by Akt inhibitor perifosine in xenografts of non-small cell lung cancer (28). Furthermore, sorafenib reversed resistance of human gastric cancer cell line to DDP through downregulating expression MDR1 and Akt (40). As a result, baicalin is able to decrease DDP resistance, and inhibit proliferation and invasion of human lung cancer cells by downregulating MARK2 and p-Akt expression.

In conclusion, we demonstrated for the first time that baicalin and DDP were synergistic at inhibiting proliferation and invasion of human lung cancer cells at appropriate dosages and incubation time in the presence or absence of DDP resistance. The attenuation of DDP resistance was associated with downregulation of MARK2 and p-Akt. Although future research is needed to elucidate more underlying cellular and molecular mechanisms, baicalin appears to be a promising agent for reducing DDP resistance.

\section{References}

1. Ferlay J, Soerjomataram I, Dikshit R, Eser S, Mathers C, Rebelo M, Parkin DM, Forman D and Bray F: Cancer incidence and mortality worldwide: Sources, methods and major patterns in GLOBOCAN 2012. Int J Cancer 136: E359-E386, 2015.

2. Belani CP: Chemotherapy regimens in advanced non-small-cell lung cancer: Recent randomized trials. Clin Lung Cancer 3 (Suppl 1): S5-S9, 2002.

3. Suehisa $\mathrm{H}$ and Toyooka S: Adjuvant chemotherapy for completely resected non-small-cell lung cancer. Acta Med Okayama 63: 223-230, 2009.

4. Li CH, Cai L, Chen XS, Meng QW and Sui GJ: DDP-sensitivityrelated genes in 10 lung cancer cell lines. Zhonghua Zhong Liu Za Zhi 30: 418-421, 2008 (In Chinese).

5. Shen Y, Ren M, Shi Y, Zhang Y and Cai Y: Octreotide enhances the sensitivity of the SKOV3/DDP ovarian cancer cell line to cisplatin chemotherapy in vitro. Exp Ther Med 2: 1171-1176, 2011.

6. Weng Y, Wang Y, Shi Y, Zhou W, Wang H and Wang C: TLR9 expression and its role in chemosensitivity to DDP in human cervical cancer cells in vitro. J Huazhong Univ Sci Technolog Med Sci 31: 550-554, 2011.

7. Chen J, Solomides C, Parekh H, Simpkins F and Simpkins H: Cisplatin resistance in human cervical, ovarian and lung cancer cells. Cancer Chemother Pharmacol 75: 1217-1227, 2015.

8. Chen Y, Gao Y, Zhang K, Li C, Pan Y, Chen J, Wang R and Chen L: MicroRNAs as regulators of cisplatin resistance in lung cancer. Cell Physiol Biochem 37: 1869-1880, 2015.

9. Müller CB, De Bastiani MA, Becker M, França FS, Branco MA Castro MA and Klamt F: Potential crosstalk between cofilin-1 and EGFR pathways in cisplatin resistance of non-small-cell lung cancer. Oncotarget 6: 3531-3539, 2015.

10. Wang H, Hui KM, Xu S, Chen Y, Wong JT and Xue H: Two flavones from Scutellaria baicalensis Georgi and their binding affinities to the benzodiazepine site of the GABAA receptor complex. Pharmazie 57: 857-858, 2002.

11. Hui KM, Wang XH and Xue H: Interaction of flavones from the roots of Scutellaria baicalensis with the benzodiazepine site. Planta Med 66: 91-93, 2000.

12. Xu Z, Wang F, Tsang SY, Ho KH, Zheng H, Yuen CT, Chow CY and Xue $\mathrm{H}$ : Anxiolytic-like effect of baicalin and its additivity with other anxiolytics. Planta Med 72: 189-192, 2006.

13. Liao JF, Hung WY and Chen CF: Anxiolytic-like effects of baicalein and baicalin in the Vogel conflict test in mice. Eur J Pharmacol 464: 141-146, 2003.

14. Tarragó T, Kichik N, Claasen B, Prades R, Teixidó M and Giralt E: Baicalin, a prodrug able to reach the CNS, is a prolyl oligopeptidase inhibitor. Bioorg Med Chem 16: 7516-7524, 2008.

15. Takahashi H, Chen MC, Pham H, Angst E, King JC, Park J, Brovman EY, Ishiguro H, Harris DM, Reber HA, et al: Baicalein, a component of Scutellaria baicalensis, induces apoptosis by Mcl-1 downregulation in human pancreatic cancer cells. Biochim Biophys Acta 1813: 1465-1474, 2011.

16. Zhang Z, Lv J, Lei X, Li S, Zhang Y, Meng L, Xue R and Li Z: Baicalein reduces the invasion of glioma cells via reducing the activity of p38 signaling pathway. PLoS One 9: e90318, 2014.

17. Chen K, Zhang S, Ji Y, Li J, An P, Ren H, Liang R, Yang J and Li Z: Baicalein inhibits the invasion and metastatic capabilities of hepatocellular carcinoma cells via downregulation of the ERK pathway. PLoS One 8: e72927, 2013.

18. Dickey CA, Koren J, Zhang YJ, Xu YF, Jinwal UK, Birnbaum MJ, Monks B, Sun M, Cheng JQ, Patterson C, et al: Akt and CHIP coregulate tau degradation through coordinated interactions. Proc Natl Acad Sci USA 105: 3622-3627, 2008.

19. Peltier J, O'Neill A and Schaffer DV: PI3K/Akt and CREB regulate adult neural hippocampal progenitor proliferation and differentiation. Dev Neurobiol 67: 1348-1361, 2007.

20. Jin ZJ: About the evaluation of drug combination. Acta Pharmacol Sin 25: 146-147, 2004

21. Parkin DM, Bray F, Ferlay J and Pisani P: Global cancer statistics, 2002. CA Cancer J Clin 55: 74-108, 2005.

22. Apps MG, Choi EH and Wheate NJ: The state-of-play and future of platinum drugs. Endocr Relat Cancer 22: R219-R233, 2015. 
23. Siddik ZH: Cisplatin: Mode of cytotoxic action and molecular basis of resistance. Oncogene 22: 7265-7279, 2003.

24. Murata T, Haisa M, Uetsuka H, Nobuhisa T, Ookawa T, Tabuchi Y, Shirakawa Y, Yamatsuji T, Matsuoka J, Nishiyama M, et al: Molecular mechanism of chemoresistance to cisplatin in ovarian cancer cell lines. Int J Mol Med 13: 865-868, 2004.

25. Wu HM, Jiang ZF, Ding PS, Shao LJ and Liu RY: Hypoxia-induced autophagy mediates cisplatin resistance in lung cancer cells. Sci Rep 5: 12291, 2015.

26. Im JY, Lee KW, Won KJ, Kim BK, Ban HS, Yoon SH, Lee YJ, Kim YJ, Song KB and Won M: DNA damage-induced apoptosis suppressor (DDIAS), a novel target of NFATc1, is associated with cisplatin resistance in lung cancer. Biochim Biophys Acta 1863: 40-49, 2016.

27. Yang Y, Zhang P, Zhao Y, Yang J, Jiang G and Fan J: Decreased MicroRNA-26a expression causes cisplatin resistance in human non-small cell lung cancer. Cancer Biol Ther 17: 515-525, 2016.

28. Wu DW, Lee MC, Hsu NY, Wu TC, Wu JY, Wang YC, Cheng YW, Chen CY and Lee H: FHIT loss confers cisplatin resistance in lung cancer via the $\mathrm{AKT} / \mathrm{NF}-\kappa \mathrm{B} / \mathrm{Slug}$-mediated PUMA reduction. Oncogene 34: 3882-3883, 2015

29. Wu C, Wangpaichitr M, Feun L, Kuo MT, Robles C, Lampidis T and Savaraj N: Overcoming cisplatin resistance by mTOR inhibitor in lung cancer. Mol Cancer 4: 25, 2005.

30. Li JH, Luo N, Zhong MZ, Xiao ZQ, Wang JX, Yao XY, Peng Y and Cao J: Inhibition of microRNA-196a may reverse cisplatin resistance of A549/DDP non-small-cell lung cancer cell line. Tumour Biol 37: 2387-2394, 2016.

31. Wang CK, Zhang Y, Zhang ZJ, Qiu QW, Cao JG and He ZM: Effects of VBMDMP on the reversal of cisplatin resistance in human lung cancer A549/DDP cells. Oncol Rep 33: 372-382, 2015.

32. Li X, Yang G, Li X, Zhang Y, Yang J, Chang J, Sun X, Zhou X, Guo Y, Xu Y, et al: Traditional Chinese medicine in cancer care: A review of controlled clinical studies published in Chinese. PLoS One 8: e60338, 2013.
33. Dong J, Su SY, Wang MY and Zhan Z: Shenqi fuzheng, an injection concocted from Chinese medicinal herbs, combined with platinum-based chemotherapy for advanced non-small cell lung cancer: A systematic review. J Exp Clin Cancer Res 29: 137, 2010.

34. Lichti-Kaiser K and Staudinger JL: The traditional Chinese herbal remedy tian xian activates pregnane $X$ receptor and induces CYP3A gene expression in hepatocytes. Drug Metab Dispos 36: 1538-1545, 2008.

35. Sui X, Chen R, Wang Z, Huang Z, Kong N, Zhang M, Han W, Lou F, Yang J, Zhang Q, et al: Autophagy and chemotherapy resistance: A promising therapeutic target for cancer treatment. Cell Death Dis 4: e838, 2013.

36. Hubaux R, Thu KL, Vucic EA, Pikor LA, Kung SH, Martinez VD, Mosslemi M, Becker-Santos DD, Gazdar AF, Lam S, et al: Microtubule affinity-regulating kinase 2 is associated with DNA damage response and cisplatin resistance in non-small cell lung cancer. Int J Cancer 137: 2072-2082, 2015.

37. Sarbassov DD, Guertin DA, Ali SM and Sabatini DM: Phosphorylation and regulation of Akt/PKB by the rictor-mTOR complex. Science 307: 1098-1101, 2005.

38. Liu LZ, Zhou XD, Qian G, Shi X, Fang J and Jiang BH: AKT1 amplification regulates cisplatin resistance in human lung cancer cells through the mammalian target of rapamycin/p70S6K1 pathway. Cancer Res 67: 6325-6332, 2007.

39. Duan S, Tsai Y, Keng P, Chen Y, Lee SO and Chen Y: IL-6 signaling contributes to cisplatin resistance in non-small cell lung cancer via the upregulation of anti-apoptotic and DNA repair associated molecules. Oncotarget 6: 27651-27660, 2015.

40. Huang YS, Xue Z and Zhang H: Sorafenib reverses resistance of gastric cancer to treatment by cisplatin through downregulating MDR1 expression. Med Oncol 32: 470, 2015. 